University of Nebraska - Lincoln

DigitalCommons@University of Nebraska - Lincoln

$12-15-2006$

\title{
Responses of Pond-Breeding Amphibians to Wildfire: Short-Term Patterns in Occupancy and Colonization
}

Blake R. Hossack

Aldo Leopold Wilderness Research Institute

Paul Stephen Corn

Aldo Leopold Wilderness Research Institute

Follow this and additional works at: https://digitalcommons.unl.edu/usgsstaffpub

Part of the Earth Sciences Commons

Hossack, Blake R. and Corn, Paul Stephen, "Responses of Pond-Breeding Amphibians to Wildfire: ShortTerm Patterns in Occupancy and Colonization" (2006). USGS Staff -- Published Research. 96.

https://digitalcommons.unl.edu/usgsstaffpub/96

This Article is brought to you for free and open access by the US Geological Survey at DigitalCommons@University of Nebraska - Lincoln. It has been accepted for inclusion in USGS Staff -- Published Research by an authorized administrator of DigitalCommons@University of Nebraska - Lincoln. 


\title{
RESPONSES OF POND-BREEDING AMPHIBIANS TO WILDFIRE: SHORT-TERM PATTERNS IN OCCUPANCY AND COLONIZATION
}

\author{
Blake R. Hossack ${ }^{1}$ and Paul Stephen Corn \\ United States Geological Survey, Aldo Leopold Wilderness Research Institute, 790 E. Beckwith Avenue, Missoula, Montana 59801 USA
}

\begin{abstract}
Wildland fires are expected to become more frequent and severe in many ecosystems, potentially posing a threat to many sensitive species. We evaluated the effects of a large, stand-replacement wildfire on three species of pond-breeding amphibians by estimating changes in occupancy of breeding sites during the three years before and after the fire burned 42 of 83 previously surveyed wetlands. Annual occupancy and colonization for each species was estimated using recently developed models that incorporate detection probabilities to provide unbiased parameter estimates. We did not find negative effects of the fire on the occupancy or colonization rates of the long-toed salamander (Ambystoma macrodactylum). Instead, its occupancy was higher across the study area after the fire, possibly in response to a large snowpack that may have facilitated colonization of unoccupied wetlands. Naïve data (uncorrected for detection probability) for the Columbia spotted frog (Rana luteiventris) initially led to the conclusion of increased occupancy and colonization in wetlands that burned. After accounting for temporal and spatial variation in detection probabilities, however, it was evident that these parameters were relatively stable in both areas before and after the fire. We found a similar discrepancy between naïve and estimated occupancy of $A$. macrodactylum that resulted from different detection probabilities in burned and control wetlands. The boreal toad (Bufo boreas) was not found breeding in the area prior to the fire but colonized several wetlands the year after they burned. Occupancy by $B$. boreas then declined during years 2 and 3 following the fire. Our study suggests that the amphibian populations we studied are resistant to wildfire and that $B$. boreas may experience short-term benefits from wildfire. Our data also illustrate how naïve presence-non-detection data can provide misleading results.
\end{abstract}

Key words: Ambystoma macrodactylum; amphibians; Bufo boreas; colonization; conservation; detection; extinction; fire; occupancy; population dynamics; Rana luteiventris.

\section{INTRODUCTION}

Population changes after disturbances such as fire may result from a variety of mechanisms operating at different temporal and spatial scales. These mechanisms include direct mortality, colonization and emigration, or succession-related changes in habitat that affect habitat suitability and community structure (Romme 1982, Pease et al. 1989, Andersen and Müller 2000, Smucker et al. 2005). Alterations to current fire regimes are expected for many ecosystems as a result of modifications to historical land uses and climate change (Stocks et al. 1998, Williams et al. 2001). In western North America, wildland fires are expected to become more frequent and severe under future ecosystem conditions (Fagre et al. 2003, Westerling et al. 2006). These projections underscore the need for an improved understanding of the effects of fire on amphibians and other potentially sensitive species in the region (Pilliod et al. 2003, Bury 2004).

Manuscript received 8 December 2006; accepted 15 December 2006. Corresponding Editor: R. A. Relyea.

${ }^{1}$ E-mail: blake_hossack@usgs.gov
Amphibians are generally considered an indicator of ecosystem health because they are sensitive to disturbance (e.g., deMaynadier and Hunter 1995, Welsh and Droege 2001). Indeed, many amphibian species are negatively affected by a wide range of disturbances such as fire (Driscoll and Roberts 1997, Gamradt and Kats 1997, Hossack et al. 2006a), and habitat change or loss is the leading identified cause of amphibian decline (Corn 2000, Stuart et al. 2004). However, as with numerous other animals (Cunningham et al. 2002, Waltz and Covington 2004, Smucker et al. 2005, Webb et al. 2005), some amphibians are resistant to periodic disturbance and may even decline without it (Beebee 1977; Dodd et al., in press). For example, several amphibian species are associated with open forest canopy around breeding wetlands (Skelly et al. 1999, Werner and Glennemeier 1999, Halverson et al. 2003), and diverse amphibian assemblages in longleaf pine (Pinus palustris) forests in the southeast United States are maintained by frequent ground fires (Means and Campbell 1981, Russell et al. 1999). For species such as these, the prolonged absence of natural disturbance may have effects similar to direct habitat loss.

Local colonization and extinction processes drive changes in distribution, often in response to natural 


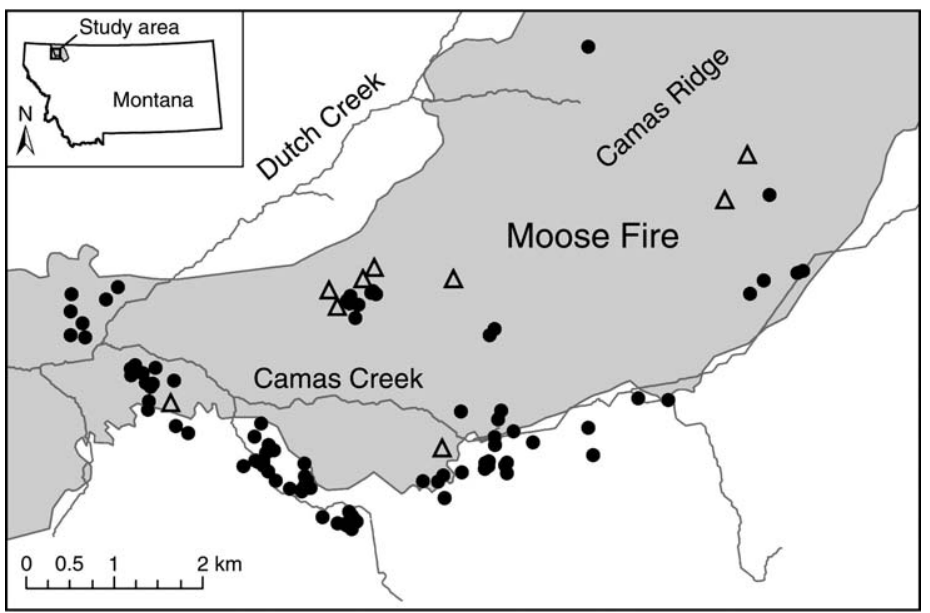

FIG. 1. Location of control and burned wetlands (solid circles) around the perimeter of the 2001 Moose Fire (shaded) in Glacier National Park, Montana, USA. The open triangles designate the burned wetlands that were colonized by breeding boreal toads (Bufo boreas) in 20022003. Note that wetlands outside the shaded area are controls, while those inside are burned.

disturbances (Petranka et al. 2004, Crisafulli et al. 2005, Smucker et al. 2005). Disturbance and forest fragmentation also frequently affects movement by amphibians (Chan-McLeod 2003, Vasconcelos and Calhoun 2004). Preference for closed canopy forests could conceivably increase emigration away from burned areas into neighboring unburned forest. Conversely, removal of vegetation may inhibit movement by some species and reduce opportunities for colonization, potentially affecting patterns of occupancy or gene flow (e.g., Donovan et al. 1995, Schwartz et al. 2002). Responses by amphibians to wildfire are likely to be species specific and dependant on habitat and population status, and thus not easily predicted. Furthermore, because large wildfires are more likely to occur during prolonged droughts (Pederson et al. 2006, Westerling et al. 2006), amphibian populations may already be stressed when fires occur.

Most research on the effects of fire on amphibians has focused on low-severity fires, often as prescribed burns that are used for management of vegetation (Russell et al. 1999, Lemckert et al. 2004). There is little information on the effects of more severe stand-replacement fires in temperate forests (Pilliod et al. 2003, Bury 2004), because these types of fires are an infrequent event and are not subject to experimental manipulation or control. We initiated the present study after a lightning-ignited wildfire burned an area in western Montana where we had already conducted three years of wetland surveys for breeding populations of the long-toed salamander (Ambystoma macrodactylum), boreal toad (Bufo boreas), and Columbia spotted frog (Rana luteiventris). The existence of pre-fire data presented a rare opportunity to document how wildfire affects pond-breeding amphibians by comparing patterns in occupancy and colonization in burned and control wetlands during the three years following the fire.

\section{STUdy AREA}

The Moose Fire started in August 2001 and burned 42 wetlands in Glacier National Park (hereafter Glacier NP) we had surveyed previously for amphibian larvae during 1999-2001 (Fig. 1, Table 1). There was a comparable number of previously surveyed wetlands just south of the fire perimeter $(n=41$; Fig. 1$)$, effectively setting up a before-after, control-impact (BACI) study, where individual wetlands are considered replicates or subsamples and temporal trends in occupancy of impacted (burned) wetlands are measured against trends in the control (unburned) area (Underwood 1992).

The Moose Fire burned $\sim 9830$ ha in the park in an area covered with mixed western larch-lodgepole pine (Larix occidentalis-Pinus contorta) forests that were historically replaced by fire every $140-340$ years (Barrett et al. 1991). Due to the naturally long fire intervals, fire

TABLE 1. Number of wetlands surveyed each year out of 41 control and 42 burned wetlands surveyed during the study.

\begin{tabular}{cccccc}
\hline \hline & \multicolumn{2}{c}{ Control } & & \multicolumn{2}{c}{ Burned } \\
\cline { 2 - 3 } Year & $\begin{array}{c}\text { No. wetlands } \\
\text { surveyed }\end{array}$ & $\begin{array}{c}\text { Mean no. } \\
\text { surveys per site }\end{array}$ & & $\begin{array}{c}\text { No. wetlands } \\
\text { surveyed }\end{array}$ & $\begin{array}{c}\text { Mean no. } \\
\text { surveys per site }\end{array}$ \\
\hline 1999 & 18 & 1.78 & & 9 & 1.89 \\
2000 & 38 & 1.21 & & 36 & 1.44 \\
2001 & 14 & 1.0 & & 38 & 1.0 \\
2002 & 41 & 2.12 & 39 & 1.97 \\
2003 & 33 & 1.39 & 38 & 2.18 \\
2004 & 34 & 2.32 & & 38 \\
\hline
\end{tabular}


suppression has not greatly altered the natural succession of forest stands in this area and the Moose Fire was an average landscape-scale fire relative to previous fires in the North Fork Flathead valley during the last 400 years (Barrett et al. 1991, Barrett 2002). Typical of wildfires in this forest type, the Moose Fire varied in severity, with areas within in the fire perimeter ranging from unburned to full stand replacement (Barrett et al. 1991).

Forests in the northwest portion of the park are densely populated with shallow wetlands in depressions left by receding Pleistocene glaciers (Rabe and Chadde 1994). Most of these wetlands fill from snowmelt in the spring, support extensive emergent vegetation communities, and then dry by early August. Consequently, almost all of our study wetlands were likely dry when the fire occurred. Visual estimates during 2002-2004 indicated that all wetlands within the fire perimeter were burned at least partially, with $\geq 70 \%$ of the perimeter burned $(\bar{x}=0.82, \mathrm{SD}=0.242)$ on 37 of the 42 wetlands within the fire perimeter.

Several aerial applications of fire-control chemicals were made on Camas Ridge (Dennis Divoky, personal communication; Fig. 1). If the chemicals affected any of our wetlands, it was only a small number and it was not evident based upon their water chemistry (B. R. Hossack et al., unpublished manuscript). Also, Camas Ridge was the portion of our study area that burned the most severely.

\section{Methods \\ Amphibian sampling}

We used visual encounter surveys to assess the use of wetlands for breeding (indicated by presence or nondetection of embryos and larvae) by the three species we studied. Surveys were conducted by searching the perimeter and shallow $(\leq 0.5 \mathrm{~m})$ areas of each wetland, using dip nets in areas with thick vegetation or where water clarity was poor (described in Adams et al. 2005). Many wetlands were sampled twice annually in 19992000 to reduce the probability of failing to detect species that were present, but only single surveys were conducted in 2001. We used the same sampling methods during the three years following the fire, with greater emphasis on surveying all wetlands at least twice per year (Table 1). Variation in number of wetlands sampled after the fire is due partially to wetlands that do not fill with water every year. A July 2003 wildfire also prevented us from completing surveys that year.

Wetland surveys were timed to coincide with the approximate six to eight week period during which larvae were expected to be present. A wetland was considered a breeding site only if embryos or larvae were detected. The 83 wetlands sampled for this study were generally of similar size $(<1.0$ ha) and depth (maximum $<1.0 \mathrm{~m}$ ). Additional wetlands were found after 2001, but only those that contained water and were surveyed prior to the fire were included in these analyses.

\section{Statistical analyses}

Naïve detection-nondetection data (uncorrected for variation in detection probability) will usually underestimate occupancy and provide biased estimates of colonization and local extinction rates, because species are rarely detected perfectly (MacKenzie et al. 2003, Bailey et al. 2004). To account for variation in detection and changes in populations over time, we used the seasonal occupancy and colonization model in PRESENCE 2.0 (MacKenzie et al. 2003) to estimate wetland occupancy (the probability of reproduction; $\hat{\Psi}$ ), colonization $(\hat{\gamma})$, and detection probability $(\hat{p})$. We chose this model because our primary interest was in measuring changes in occupancy in control and burned wetlands relative to the timing of the fire. We also suspected that colonization by at least two of the species had increased after 2001, possibly in response to the fire.

The multi-season model assumes spatial independence among populations in the sense that wetlands are closed to changes in occupancy within a season (i.e., occupancy does not change between surveys within each summer), but allows for colonization and local extinction between seasons. Models that explicitly account for the effects of neighboring populations on changes in occupancy and vital rates between years have not been developed (MacKenzie et al. 2006). PRESENCE accommodates missing data (i.e., sites that were not surveyed some years) and uses repeated surveys of wetlands to estimate species-specific detection probabilities and provide unbiased estimates of occupancy and vital rates. Local extinction can be derived from estimates of seasonspecific occupancy and colonization probabilities obtained with the model parameterization we used (MacKenzie et al. 2006).

To determine whether the fire affected occupancy and vital rates, we divided wetlands into control and burned groups based on whether or not they were within the fire perimeter. We then found the combination of covariates that provided the best description of the detection probability for each species (based on the Akaike Information Criterion [AIC]). Variation in detection probability was considered a nuisance parameter; our goal was to account for possible spatial and temporal variation in detection probability so that it would not bias our inferences about occupancy and colonization probabilities, the parameters of interest. Therefore, we explored combinations of three detection probability structures: one that represented possible detection probability differences among spatial locations (within or outside the fire), one that estimated separately the detection probabilities during the first two years of the study, and one that estimated separately the pre- and post-fire detection probabilities. We suspected detection might have been lower during the first two years of the study because local breeding phenology was not well known and all observers were new to the area. Following 2000, we had a high return rate of field technicians and thus expected higher detection proba- 
bilities in subsequent years. We also suspected that detection might change as a result of the fire.

Amphibian populations in control and burned wetlands may have had different initial occupancy and vital rates unrelated to the fire; therefore, we attempted to separate spatial variation, temporal variation, and fire effects in the analysis by focusing on three covariates: location (control vs. burned wetlands), time (before vs. after the fire), and a fire effect term that evaluated the interaction of location and time (e.g., Underwood 1992). We also estimated parameters using only an intercept, which assumes the parameter was constant throughout the study. If the fire affected the distribution of breeding populations, it should be evident by greater levels of support for models that estimate a fire effect.

Each of the three covariates plus the fixed parameters was fitted in combination to the occupancy and colonization parameters, resulting in 16 models each for A. macrodactylum and $R$. luteiventris (Appendix). Support for models was measured by Akaike weights (w). Model-weighted occupancy and colonization parameters were calculated for burned and control wetlands, before and after the fire, based on the entire candidate model set because no model clearly provided the best representation to either dataset (Burnham and Anderson 2002). Two of the A. macrodactylum models had indefinite solutions to the variance-covariance matrix, indicating that more than one solution was possible. We retained these models (Appendix) but did not use the parameter estimates when averaging across the model set.

We did not detect $B$. boreas breeding in any wetland before the fire. Consequently, we only fit the post-fire data to a model that assumed vital rates were constant among years. We also had to trim some of the post-fire data to make the data set more balanced. Specifically, three wetlands where we collected several water chemistry samples (B. R. Hossack et al., unpublished manuscript) were sampled five to eight times in 2002, but most other wetlands were only sampled twice, so sampling events 5-8 were deleted. Deletion of these sampling events did not alter the detection of occupancy at any wetland. The data for $A$. macrodactylum and $R$. luteiventris remained unchanged.

We did not assess the effect of wetland characteristics on occupancy or colonization because a concurrent study indicated that there were few differences in water chemistry, temperature, or habitat features of control and burned wetlands (B. R. Hossack et al., unpublished manuscript), and because our pre-fire data was usually too sparse to successfully fit models with habitat covariates.

\section{Results}

Ambystoma macrodactylum

After controlling for spatial variation in detection, there was no evidence that the fire negatively affected the distribution of A. macrodactylum. The two best-sup-
TABLE 2. Model-averaged estimates (and SE) of occupancy $(\hat{\Psi})$ and colonization $(\hat{\gamma})$ for the long-toed salamander (Ambystoma macrodactylum) and Columbia spotted frog (Rana luteiventris) in control and burned wetlands, before (1999-2001) and after (2002-2004) the Moose Fire, and detection probabilities $(\hat{p})$.

\begin{tabular}{ccc}
\hline \hline \multicolumn{1}{c}{ Parameter } & Control & Burned \\
\hline Ambystoma macrodactylum & & \\
$\hat{\Psi}_{1999-2001}$ & $0.89(0.036)$ & $0.86(0.040)$ \\
$\Psi_{1999-2001}$ & 0.82 & 0.69 \\
$\hat{\Psi}_{2002-2004}$ & $0.91(0.028)$ & $0.89(0.032)$ \\
$\Psi_{2002-2004}$ & 0.92 & 0.87 \\
$\hat{\gamma}_{1999-2001}$ & $0.20(0.131)$ & $0.46(0.187)$ \\
$\hat{\gamma}_{2002-2004}$ & $0.42(0.165)$ & $0.75(0.153)$ \\
$\hat{p}_{1999-2004}$ & $0.89(0.020)$ & $0.85(0.026)$ \\
Rana luteiventris & & \\
$\hat{\Psi}_{1999-2001}$ & $0.38(0.057)$ & $0.40(0.058)$ \\
$\Psi_{1999-2001}$ & 0.34 & 0.25 \\
$\hat{\Psi}_{2002-2004}$ & $0.38(0.055)$ & $0.40(0.057)$ \\
$\Psi_{2002-2004}$ & 0.31 & 0.37 \\
$\hat{\gamma}_{1999-2001}$ & $0.06(0.032)$ & $0.06(0.031)$ \\
$\hat{\gamma}_{2002-2004}$ & $0.07(0.025)$ & $0.08(0.025)$ \\
$\hat{p}_{1999-2000}$ & $0.66(0.084)$ & $0.46(0.094)$ \\
$\hat{p}_{2001-2004}$ & $0.84(0.044)$ & $0.69(0.050)$ \\
\hline
\end{tabular}

Notes: Naïve occupancy ( $\Psi$, uncorrected for detection probability) is shown along with estimates of the probability of occupancy, $\hat{\Psi}$, for each combination of time and location. Detection probability $(\hat{p})$ was estimated separately for control and burned wetlands (1999-2004) for A. macrodactylum, and for control and burned wetlands during the years 1999-2000 and 2001-2004 for R. luteiventris.

ported models (33\% of model weights) estimated that occupancy was approximately constant throughout the study (Table 2; Appendix). The highest ranked model that described a fire effect on occupancy received little support $(w=0.06)$, and the fire effect coefficient was positive in that, and all other models, with a fire effect (Appendix). Averaged across all models, occupancy in control wetlands was slightly higher than in burned wetlands before and after the fire (Fig. 1, Table 2). Models that estimated a fire effect on occupancy probability produced the highest values (up to 0.96) of any of the models. In contrast, when occupancy was described as a constant parameter across all wetlands, estimated occupancy was only 0.88 and resulted in a model-averaged estimate for the post-fire, control wetlands that was lower than the naïve value (obtained from the subset of control sites only).

The higher occupancy estimates after the fire were caused by increased colonization in both groups of wetlands. The positive coefficients for all models that estimated a fire effect on the colonization rates suggests that colonization increased more in burned wetlands after the fire, but the support was weak (combined weight of $\hat{\gamma}$ [fire] models $=0.31$; Table 2, Appendix). In a post hoc analysis, we investigated the post-fire increase in colonization by modifying the best-supported model for A. macrodactylum to estimate colonization rates separately for each year after the fire ( $\hat{\gamma}$ [location, 2002, 2003, 2004]). We suspected the 2002 data had the largest influence on the post-fire estimates, because of an 


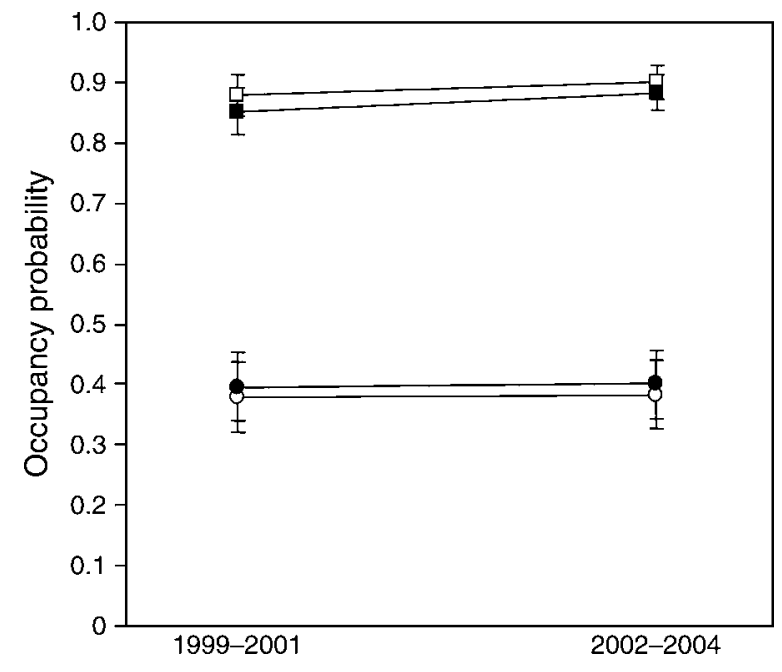

FIG. 2. Model-averaged estimates of occupancy probability (mean $\pm \mathrm{SE}$ ) for the long-toed salamander (Ambystoma macrodactylum; squares) and Columbia spotted frog (Rana luteiventris; circles) in control (open symbols) and burned (solid symbols) wetlands before and after the August 2001 Moose Fire.

unusually deep snowpack that year. Therefore, we fit two additional models that described colonization in 2003 and 2004 as equal ( $\hat{\gamma}$ [location, 2002, 2003-2004]) as well as a model where all years were equal except $2002(\hat{\gamma}$ [location, 2002]). Models to estimate colonization separately for each year could not be fitted to our data.

The trend toward greater occupancy and colonization in all wetlands during the three years after the fire was most likely due to the 2002 data (Table 2). The model that estimated colonization for 2002 separately and all other years as equal received the most support, although the greatest difference in AIC value of the three post hoc colonization models was only 0.91 , indicating a lack of clear support for any particular model (Burnham and Anderson 2002). The $\hat{\gamma}$ (location, 2002) model estimated that all wetlands that were vacant in 2001 were colonized in 2002.

\section{Rana luteiventris}

The fire had no effect on occupancy or colonization by $R$. luteiventris. There is considerable model uncertainty, but the model that described occupancy and colonization as constant parameters received the most support (Appendix), and model-averaged estimates for annual occupancy during the three years before and after the fire were nearly identical (Fig. 2, Table 2). Only two models had had negative fire-effect coefficients, and they received a combined model weight of $6 \%$, which is strong evidence against a negative effect. Modelaveraged estimates show that colonization increased slightly in all wetlands after the fire even though three of the top five $R$. luteiventris models described colonization as constant over space and time.
The naïve detection data for $R$. luteiventris suggested a $9 \%$ decrease in occupancy in control wetlands and a $50 \%$ increase in burned wetlands after the fire (Table 2), which could have been interpreted as strong evidence of a positive fire effect. The naïve data were misleading because of detection differences between burned and control wetlands: detection probability of $R$. luteiventris was lower in burned wetlands throughout the study, but showed a more substantial increase at burned wetlands following the 2000 season. Similarly, naïve detections alone would have indicated that $A$. macrodactylum occupancy increased in burned wetlands by nearly 3 times that of control wetlands ( $23 \%$ vs. $8 \%$, respectively) because of the larger pre-fire adjustment to occupancy in the wetlands that eventually burned.

\section{Bufo boreas}

Bufo boreas had not been found breeding in either group of wetlands prior to the Moose Fire. After the fire, we found evidence of breeding in seven burned wetlands in 2002, in three burned wetlands in 2003, and in 0 wetlands in 2004 (Fig. 1). Larvae were never found in any control wetland. The intercepts-only model fitted to the post-fire data estimated $\hat{\Psi}=0.05(\mathrm{SE}=0.035), \hat{\gamma}=$ $0.04(0.032)$, and $\hat{p}=0.92(0.082)$ for the three years after the fire. If we make the assumption that there were no false absences recorded at control wetlands and analyze the data from the 42 burned wetlands separately, estimated annual occupancy for burned wetlands during the three years after the fire was 0.09 (0.037). Much of the $B$. boreas breeding activity was concentrated around one cluster of wetlands, but several other breeding locations were widespread within the fire perimeter (Fig. 1).

\section{DisCUSSION}

We did not find any evidence that suggests that the Moose Fire negatively affected occupancy or vital rates of the three amphibians we studied. We expected that the fire would be most likely to negatively affect $A$. macrodactylum, because salamanders are generally more sensitive to the indirect effects of disturbance than are anurans (deMaynadier and Hunter 1995). However, we did not find a reduction in occupancy by A. macrodactylum after the fire, even in areas that burned the most severely. Instead, occupancy increased slightly throughout the study area in the years following the fire. Ambystoma macrodactylum may be less vulnerable to habitat changes than many other salamanders because it occupies a wide range of habitats in the Northwest and is found in most fishless ponds even in highly fragmented landscapes (Monello and Wright 1999, Pearl et al. 2005). It is likely there was actually an increase in number of $A$. macrodactylum breeding sites within the fire perimeter because trees that fell across temporary streams created several new wetlands.

Colonization of unoccupied wetlands by A. macrodactylum was also not affected by the fire. We consider 
estimates of colonization an indirect index of dispersal, although colonization and extinction patterns may also reflect intermittent breeding by resident individuals. Colonization by $A$. macrodactylum was highest in 2002 , the year with largest snowpack, suggesting that the large and late-melting snowpack could have facilitated overland travel and immigration by salamanders. The comparatively sparse pre-fire data and our inability to estimate annual colonization rates limit the conclusions we can make, but the relationship between colonization and snowpack merits further investigation.

Based on naïve estimates, we had previously concluded that occupancy by the Columbia spotted frog $(R$. luteiventris) increased in wetlands that burned (Hossack and Corn 2004). After incorporating detection probabilities, it was evident that occupancy was stable throughout the study area during the three years before and after the fire. The different conclusions were the result of lower detection probabilities in burned wetlands throughout the study. Detection probability also increased more in burned than in control wetlands, reducing the difference between the two groups over time and resulting in an apparent increase in colonization and occupancy. We suspect the increased detection during the study resulted from an improved understanding of the local breeding phenology, which resulted in better timing of surveys, as well as more experienced field crews. We are not sure why detection differed between burned and control wetlands for both $A$. macrodactylum and $R$. luteiventris. Schmidt (2005) also found that detection of amphibians varied among years and species despite the use of standardized surveys. These results emphasize the importance of estimating detection to get unbiased estimates of occupancy and vital rates, rather than assuming it is equal in neighboring study areas or over time.

As with $A$. macrodactylum, there was frequent colonization and local extinction of $R$. luteiventris breeding sites that was unrelated to the fire. The frequent turnover suggests only a few females oviposited in most wetlands that we surveyed, and is congruent with genetic data showing that populations of these and other amphibian species often encompass more than one breeding site (Tallmon et al. 2000, Newman and Squire 2001, Funk et al. 2004, 2005). Frequent movement among closely spaced wetlands is probably more appropriately viewed as local populations sampling different portions of the landscape each year rather than true colonization or extinction events (e.g., Carlson and Edenhamn 2000, Petranka et al. 2004) and is likely to increase variation in occupancy over time (Schmidt 2005).

Bufo boreas responded positively to the fire by colonizing several recently burned wetlands. Nine burned wetlands were used for breeding during the two years after the fire in an area where no breeding had been detected and adults were rarely seen. Reproduction in burned wetlands seemed to return to pre-fire levels by the third year after the fire, when numerous males but few females were seen and we did not find larvae in any wetland. Oviposition was witnessed at one burned wetland in 2004 (G. Guscio, personal communication); however, the egg string was likely consumed or stranded, because surveys of the site by G. Guscio and us within one week after oviposition failed to detect eggs or larvae. Observations of numerous juvenile toads within the fire perimeter during the years after the fire suggest there was recruitment from some wetlands.

Bufo boreas larvae were also found the year after the fire in three additional burned wetlands that were checked at least once prior to the fire and were dry. Many of the occupied wetlands were concentrated in the same area where these previously-dry wetlands were found to be occupied after the fire. Two of these three wetlands were used for breeding again in 2006 (when only previous $B$. boreas breeding sites were surveyed), so it is conceivable that we documented an expansion of breeding effort after the fire, rather than colonization from outside of our study area. The use of wetlands for breeding that are available some years but not others raises questions about how to incorporate changes in availability of breeding sites or other resources into monitoring programs. Local populations may be considered extinct in years when wetlands are dry, but it is not known whether previous breeders skip breeding opportunities (e.g., Muths et al. 2006) or migrate to other available wetlands to breed.

Although the reasons are unclear, wildfire seems to create favorable conditions for B. boreas, at least in the short term. Colonization of previously unoccupied wetlands was repeated after another fire in 2003 in Glacier National Park that burned just to the south of our reference area. We found B. boreas breeding in $>20$ wetlands the year after that wildfire burned an area where extensive surveys had identified only three breeding sites between 1999 and 2002 (B. R. Hossack and P. S. Corn, unpublished data). Hypotheses to explain the apparent attraction of recently burned habitats include (1) the terrestrial environment provides more optimal thermal conditions for juveniles and adults ( $G$. Guscio and L. Eby, unpublished report to USGS), and (2) burned wetlands provide better oviposition habitats (Hossack et al. 2006b). However, we found no differences in the temperature of burned wetlands that were used for breeding compared to those that were not used (B. R. Hossack et al., unpublished manuscript). Bufo boreas responds favorably to a wide variety of disturbances that create or mimic early successional habitats (Crisafulli et al. 2005, Pearl and Bowerman 2006), which may indicate that our observations correspond to a generalized disturbance response. Unless all of the colonizers in the Crisafulli et al. (2005) and Pearl and Bowerman (2006) studies and our dataset were first-time breeders, these data also imply that adult $B$. boreas may frequently fill the role of colonizers. 
Our results agree with other studies showing that most pond-breeding amphibians are resistant to fire, and that some species benefit from fire (reviewed by Russell et al. 1999, Pilliod et al. 2003). However, we examined the response of three habitat-generalist amphibians; results will vary among fires and species, and may differ in areas that have been managed or where the natural forest succession has been altered. For example, increased erosion after wildfires in southern California altered stream morphology to the detriment of the California red-legged frog ( $R$. draytonii) but benefited the arroyo toad (B. californicus), both federally listed endangered species (Hitchcock et al. 2004, Mendelsohn et al. 2005). Changes to amphibian populations affected by the 2001 Moose Fire could still occur if juvenile survival is lower than in areas that did not burn. Studies after other wildfires are needed to determine if our results are broadly applicable in the region, and how wildfire affects the long-term dynamics of amphibian populations. Better knowledge of effects of fire on amphibians is required for the development of effective management policies, especially considering the projections of future fire scenarios in western forests (Fagre et al. 2003, Westerling et al. 2006).

\section{ACKNOWLedgments}

Funding was provided by the U.S. Department of the Interior's Amphibian Research and Monitoring Initiative. We thank the numerous field technicians who have helped with this study, as well as the administrative and backcountry staff of Glacier National Park. Discussions with D. MacKenzie, J. Hines, and L. Bailey about data analysis helped greatly, and comments by C. Pearl, E. Muths, L. Bailey, and L. Eby improved the manuscript.

\section{Literature Cited}

Adams, M. J., B. R. Hossack, R. A. Knapp, P. S. Corn, S. A. Diamond, P. C. Trenham, and D. B. Fagre. 2005. Distribution patterns of lentic-breeding amphibians in relation to ultraviolet radiation exposure in western North America. Ecosystems 8:488-500.

Andersen, A. N, and W. J. Müller. 2000. Arthropod responses to experimental fire regimes in an Australian tropical savannah: ordinal-level analysis. Austral Ecology 25:199209.

Bailey, L. L., T. R. Simmons, and K. H. Pollock. 2004. Estimating site occupancy and species detection probability parameters for terrestrial salamanders. Ecological Applications 14:692-702.

Barrett, S. W. 2002. Moose Fire: the historical perspective. Fire Management Today 62:42-44.

Barrett, S. W., S. F. Arno, and C. H. Key. 1991. Fire regimes of western larch-lodgepole pine forests in Glacier National Park, Montana. Canadian Journal of Forest Research 21: 1711-1720.

Beebee, T. J. C. 1977. Environmental change as a cause of natterjack toad (Bufo calamita) declines in Britain. Biological Conservation 11:87-102.

Burnham, K. P., and D. R. Anderson. 2002. Model selection and multi-model inference: a practical information-theoretic approach. Springer, New York, New York, USA.

Bury, R. B. 2004. Wildfire, fuel reduction, and herpetofaunas across diverse landscape mosaics in Northwestern forests. Conservation Biology 18:968-975.
Carlson, A., and P. Edenhamn. 2000. Extinction and the regional persistence of a tree frog metapopulation. Proceedings of the Royal Society of London. Series B, Biological Sciences 267:1311-1313.

Chan-McLeod, A. C. A. 2003. Factors affecting the permeability of clearcuts to red-legged frogs. Journal of Wildlife Management 67:663-671.

Corn, P. S. 2000. Amphibian declines: review of some current hypotheses. Pages 663-696 in D. W. Sparling, G. Linder, and C. A. Bishop, editors. Ecotoxicology of amphibians and reptiles. SETAC Press, Pensacola, Florida, USA.

Crisafulli, C. M., L. S. Trippe, C. P. Hawkins, and J. A. MacMahon. 2005. Amphibian responses to the 1980 eruption of Mount St. Helens. Pages 183-197 in V. H. Dale, F. J. Swanson, and C. M. Crisafulli, editors. Ecological responses to the 1980 eruption of Mount St. Helens. Springer, New York, New York, USA.

Cunningham, S. C., R. D. Babb, T. R. Jones, B. D. Taubert, and R. Vega. 2002. Reaction of lizard populations to a catastrophic wildfire in a central Arizona mountain range. Biological Conservation 107:193-201.

deMaynadier, P. G., and M. L. Hunter, Jr. 1995. The relationship between forest management and amphibian ecology: a review of the North American literature. Environmental Reviews 3:230-261.

Dodd, C. K., Jr., W. J. Barichivich, and S. A. Johnson. In press. Changes in a northwestern Florida Gulf Coast herpetofaunal community over a 28-year period. American Midland Naturalist.

Donovan, T. M., R. H. Lamberson, A. Kimber, F. R. Thompson III, and J. Faaborg. 1995. Modeling the effects of habitat fragmentation on source and sink demography of neotropical migrant birds. Conservation Biology 9:13961407.

Driscoll, D. A., and J. D. Roberts. 1997. Impact of fuelreduction burning on the frog Geocrinia lutea in southwest Western Australia. Australian Journal of Ecology 22:334339.

Fagre, D. B., D. L. Peterson, and A. E. Hessl. 2003. Taking the pulse of mountains: ecosystem responses to climatic variability. Climate Change 59:263-282.

Funk, W. C., M. S. Blouin, P. S. Corn, B. A. Maxell, D. S. Pilliod, S. A. Amish, and F. W. Allendorf. 2005. Population structure of Columbia spotted frogs (Rana luteiventris) is strongly affected by the landscape. Molecular Ecology 14: 483-496.

Funk, W. C., A. E. Greene, P. S. Corn, and F. W. Allendorf. 2004. High dispersal in a frog species suggests that it is vulnerable to habitat fragmentation. Biology Letters 1:13-16.

Gamradt, S. C., and L. B. Kats. 1997. Impact of chaparral wildfire-induced sedimentation on oviposition of streambreeding California newts (Taricha torosa). Oecologia 110: 546-549.

Halverson, M. A., D. K. Skelly, J. M. Kiesecker, and L. K. Freidenburg. 2003. Forest mediated light regime linked to amphibian distribution and performance. Oecologia 134: 360-364.

Hitchcock, C., A. Backlin, M. Warburton, A. Atkinson, and R. Fisher. 2004. Population monitoring and status of the California red-legged frog (Rana aurora draytonii) and unarmored threespine stickleback (Gasterosteus aculeatus williamsoni) in the Angeles National Forest, 2003. USGS Technical Report to Angeles National Forest. U.S. Geological Survey, San Diego, California, USA.

Hossack, B. R., and P. S. Corn. 2004. Responses of pondbreeding amphibians to wildfire in Glacier National Park (abstract). Northwestern Naturalist 85:78.

Hossack, B. R., P. S. Corn, and D. B. Fagre. 2006a. Divergent patterns of abundance and age-class structure of headwater stream tadpoles in burned and unburned watersheds. Canadian Journal of Zoology 84:1482-1888. 
Hossack, B. R., S. A. Diamond, and P. S. Corn. $2006 b$ Distribution of boreal toad populations in relation to estimated UV-B dose in Glacier National Park, Montana, USA. Canadian Journal of Zoology 84:98-107.

Lemckert, F. L., T. Brassil, and A. Haywood. 2004. Effects of a low intensity fire on populations of pond breeding anurans in mid-northern New South Wales, Australia. Applied Herpetology 1:183-195.

MacKenzie, D. I., J. D. Nichols, J. E. Hines, M. G. Knutson, and A. B. Franklin. 2003. Estimating site occupancy, colonization, and local extinction when a species is detected imperfectly. Ecology 84:2200-2207.

MacKenzie, D. I., J. D. Nichols, J. A. Royle, K. H. Pollock, L. L. Bailey, and J. E. Hines. 2006. Occupancy estimation and modeling: inferring patterns and dynamics of species occurrence. Elsevier, San Francisco, California, USA.

Means, D. B., and H. W. Campbell. 1981. Effects of prescribed burning on amphibians and reptiles. Pages 89-97 in G. W. Wood, editor. Prescribed fire and wildlife in southern forests. The Belle W. Baruch Forest Science Institute of Clemson University, Georgetown, South Carolina, USA.

Mendelsohn, M. B., M. C. Madden-Smith, and R. N. Fisher. 2005. Post-Cedar Fire arroyo toad (Bufo californicus) monitoring surveys at Cuyamaca Rancho State Park, 2004. USGS Technical Report to California State Parks. U.S. Geological Survey, San Diego, California, USA.

Monello, R. J., and R. G. Wright. 1999. Amphibian habitat preferences among artificial ponds in the Palouse region of northern Idaho. Journal of Herpetology 33:298-303.

Muths, E., R. D. Scherer, P. S. Corn, and B. R. Lambert. 2006. Estimation of the probability of male toads to return to the breeding site. Ecology 87:1048-1056.

Newman, R. A., and T. Squire. 2001. Microsatellite variation and fine-scale population structure in the wood frog (Rana sylvatica). Molecular Ecology 10:1087-1100.

Pearl, C. A., M. J. Adams, N. Leuthold, and R. B. Bury. 2005. Amphibian occurrence and aquatic invaders in a changing landscape: implications for wetland mitigation in the Willamette Valley, Oregon, USA. Wetlands 25:76-88.

Pearl, C. A., and J. Bowerman. 2006. Rapid colonization of constructed ponds by western toads (Bufo boreas) in central and eastern Oregon, USA. Western North American Naturalist 66:397-401.

Pease, C. M., R. Lande, and J. J. Bull. 1989. A model of population growth, dispersal and evolution in a changing environment. Ecology 70:1657-1664.

Pederson, G. T., S. T. Gray, D. B. Fagre, and L. J. Graumlich. 2006. Long-duration drought variability and impacts on ecosystem services: a case study from Glacier National Park, USA. Earth Interactions 10:1-28.

Petranka, J. W., C. K. Smith, and A. F. Scott. 2004. Identifying the minimal demographic unit for monitoring pond-breeding amphibians. Ecological Applications 14:1065-1078.

Pilliod, D. S., R. B. Bury, E. J. Hyde, C. A. Pearl, and P. S. Corn. 2003. Fire and amphibians in North America. Forest Ecology and Management 178:163-181.

Rabe, F. W., and S. W. Chadde. 1994. Classification of aquatic and semiaquatic wetland natural areas in Idaho and western Montana. Natural Areas Journal 14:175-187.
Romme, W. H. 1982. Fire and landscape diversity in subalpine forests of Yellowstone National Park. Ecological Monographs 52:199-221.

Russell, K. R., D. H. Van Lear, and D. C. Guynn, Jr. 1999. Prescribed fire effects on herpetofauna: review and management implications. Wildlife Society Bulletin 27:374-384.

Schmidt, B. R. 2005. Monitoring the distribution of pondbreeding amphibians when species are detected imperfectly. Aquatic Conservation: Marine and Freshwater Ecosystems 15:681-692.

Schwartz, M. K., L. S. Mills, K. S. McKelvey, L. F. Ruggiero, and F. W. Allendorf. 2002. DNA reveals high dispersal synchronizing the population dynamics of Canada lynx. Nature 415:520-522.

Skelly, D. K., E. E. Werner, and S. A. Cortwright. 1999. Longterm distributional dynamics of a Michigan amphibian assemblage. Ecology 80:2326-2337.

Smucker, K. M., R. L. Hutto, and B. M. Steele. 2005. Changes in bird abundance after wildfire: importance of fire severity and time since fire. Ecological Applications 15:1535-1549.

Stocks, B. J., M. A. Fosberg, T. J. Lynham, L. Mearns, B. M. Wotton, Q. Yang, J-Z. Jin, K. Lawrence, G. R. Hartley, J. A. Mason, and D. W. McKenney. 1998. Climate change and fire potential in Russian and Canadian boreal forests. Climatic Change 38:1-13.

Stuart, S. N., J. S. Chanson, N. A. Cox, B. E. Young, A. S. L. Rodrigues, D. L. Fischman, and R. W. Waller. 2004. Status and trends of amphibian declines and extinctions worldwide. Science 306:1783-1786

Tallmon, D. A., W. C. Funk, W. W. Dunlap, and F. W. Allendorf. 2000. Genetic differentiation among long-toed salamander (Ambystoma macrodactylum) populations. Copeia 2000:27-35.

Underwood, A. J. 1992. Beyond BACI: the detection of environmental impacts on populations in the real, but variable, world. Journal of Experimental Marine Biology and Ecology 161:145-178.

Vasconcelos, D., and A. J. K. Calhoun. 2004. Movement patterns of adult and juvenile Rana sylvatica (LeConte) and Ambystoma maculatum (Shaw) in three restored seasonal ponds in Maine. Journal of Herpetology 38:551-561.

Waltz, A. E., and W. W. Covington. 2004. Ecological restoration treatments increase butterfly richness and abundance: mechanisms of response. Restoration Ecology 12:8596.

Webb, J. K., R. Shine, and R. M. Pringle. 2005. Canopy modification restores habitat quality for an endangered snake in a fire suppressed landscape. Copeia 2005:894-900.

Welsh, H. H., Jr., and S. Droege. 2001. A case for using plethodontid salamanders for monitoring biodiversity and ecosystem integrity of North American forests. Conservation Biology 15:558-569.

Werner, E. E., and K. S. Glennemeier. 1999. Influence of forest canopy cover on the breeding pond distributions of several amphibian species. Copeia 1999:1-12.

Westerling, A. L., H. G. Hidalgo, D. R. Cayan, and T. W. Swetnam. 2006. Warming and earlier spring increases western U.S. forest fire activity. Science 313:940-943.

Williams, A. A. J., D. J. Karoly, and N. Taper. 2001. The sensitivity of Australian fire danger to climate change. Climatic Change 49:171-191.

\section{APPENDIX}

Summary of the 16 models used to estimate occupancy $(\hat{\Psi})$ and colonization $(\hat{\gamma})$ rates for the long-toed salamander $($ Ambystoma macrodactylum) and Columbia spotted frog (Rana luteiventris) (Ecological Archives A017-053-A1). 